\title{
The presence of accessory soleous muscle in humans
}

\author{
Estudo da presença do músculo sóleo acessório em humanos \\ Flavio Belmont Del Nero ${ }^{1}$, Cristiane Regina Ruiz ${ }^{1}$, Roberto Aliaga Junior ${ }^{1}$
}

\begin{abstract}
Objective: To verify the prevalence of the accessory soleus muscle in humans and according to gender. Methods: A total of 154 magnetic resonance images of the ankle were assessed in T1 weighted sagittal, coronal and axial planes. Results: An incidence of $11.6 \%$ of accessory soleus muscle in humans was observed; in that, $7.8 \%$ in males and $15.6 \%$ in females. Conclusion: The accessory soleus muscle incidence was $11.6 \%$ in the samples studied and it was more often present in females.
\end{abstract}

Keywords: Muscle, skeletal/abnormalities; Diagnostic imaging; Ankle; Magnetic resonance spectroscopy

\section{RESUMO}

Objetivo: Verificar a prevalência do músculo sóleo acessório em humanos e em relação ao gênero. Métodos: Foram observadas 154 imagens de ressonância magnética do tornozelo em cortes sagitais, coronais e axiais ponderadas em T1. Resultados: Observamos a incidência de 11,6\% do músculo sóleo acessório em humanos - 7,8\% em indivíduos do gênero masculino e 15,6\% em indivíduos do gênero feminino. Conclusão: 0 músculo sóleo acessório teve incidência de $11,6 \%$ nas amostras estudadas e sua presença foi maior em indivíduos do gênero feminino.

Descritores: Músculo esquelético/anormalidades; Diagnóstico por imagem; Tornozelo; Espectroscopia de ressonância magnética

\section{INTRODUCTION}

The accessory soleus muscle (ASM) is at the posterior aspect of the ankle ${ }^{(1)}$, is innervated by the posterior tibial nerve and blood supply fed by the tibial artery. According to anatomical studies, it is present in 0.7 to $5.5 \%$ of humans ${ }^{(2)}$. It is a rare anatomical variation that can present as a soft tissue tumor in this region.
A congenital muscle anomaly is more frequent in the upper limbs and is rarely seen in the lower limbs. It is seldom mentioned in the pediatric literature. During embryogenesis the soleous muscle separates into two parts, and this supernumerary muscle has its own blood supply and innervation ${ }^{(3)}$.

The ASM was first described in literature by Fue Cruvelhier, in 1834. Since then, hundreds of cases have been published highlighting the crucial relevance of a possible soft tissue tumor. This benign disease can cause pain related to physical activity, especially in adults ${ }^{(3)}$.

This supernumerary muscle is located under the gastrocnemius muscle, in the posterior upper third of the fibula, in the oblique soleus line, between the fibular head and the posterior part of the tibia. From its origin, the ASM runs anteriorly and medially until it reaches the Achilles tendon.

Five ASM types were described based on their insertion characteristics, including the Achilles tendon, the muscle insertion in the upper calcaneus region, the tendon insertion in the upper calcaneus, the muscle insertion in the medial calcaneus region, and finally the tendon insertion in the medial part of the calcaneus ${ }^{(2)}$.

The study of anatomic variations is very important to morphology researchers and healthcare professionals both for diagnosis and rehabilitation. With this study we hope to contribute with updated data on ASM prevalence in human beings and as to gender distribution, thus assisting these professionals in their work.

\section{OBJECTIVE}

To verify the prevalence of the accessory soleus muscle in humans and according to gender.

Study carried out at Centro Universitário São Camilo - São Paulo (SP), Brazil.

${ }^{1}$ Centro Universitário São Camilo - São Paulo (SP), Brazil.

Corresponding author: Cristiane Regina Ruiz - Centro Universitário São Camilo - Avenida Nazaré, 1501 - Ipiranga - Zip code: $04263-200$ - São Paulo (SP) Brazil - Phone.: (11) 2069-4000 -

E-mail: crisruiz@saocamilo-sp.br

Conflict of interest: None

Received on: Oct 6, 2011 - Accepted on: Jan 12, 2012 


\section{METHODS}

A total of 154 patients were randomly selected - 77 females and 77 males - and studied by means of MRI sequences of the ankle, T1-weighted sagittal, coronal, and axial planes. MRI was chosen for showing soft tissue characteristics and enabling observation of the precise muscle contour. Images were studied using the Onis 2.2 Free Edition software. Inclusion and description criteria were to assess only ASM reaching the calcaneus tendon insertion at the calcaneus bone and the soleus muscles that were directly inserted in the calcaneus bone (Figures 1 - 4). Soleus muscles inserted in the distal part of the calcaneus tendon were excluded.

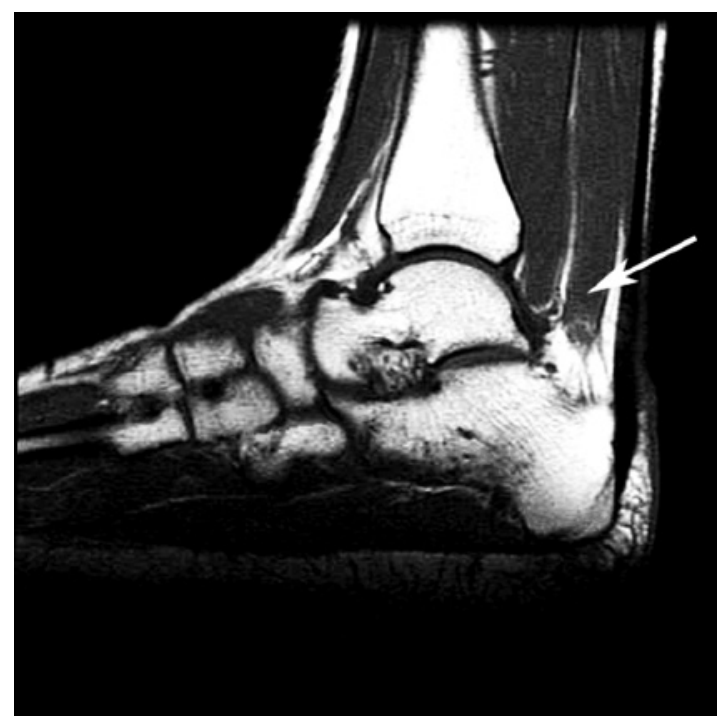

Figure 1. Accessory soleus muscle inserted in the calcaneus bone (white arrow)

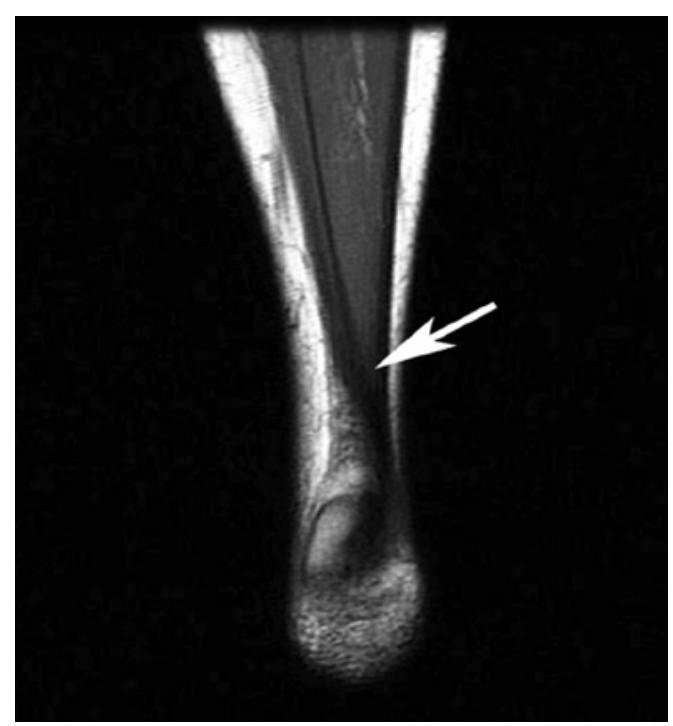

Figure 2. Accessory soleus muscle inserted in the calcaneus tendon close to the calcaneus bone MRI coronal plane (white arrow)

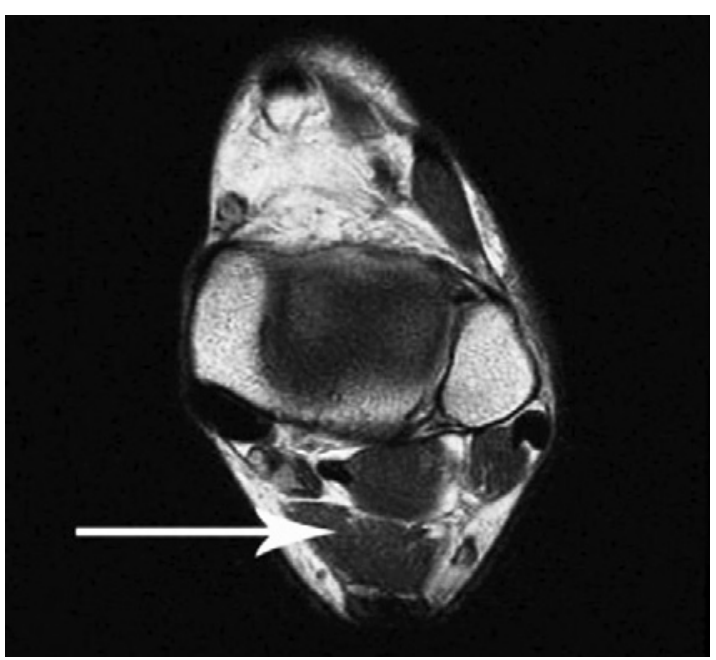

Figure 3. Accessory soleus muscle inserted in MRI axial plane (white arrow)

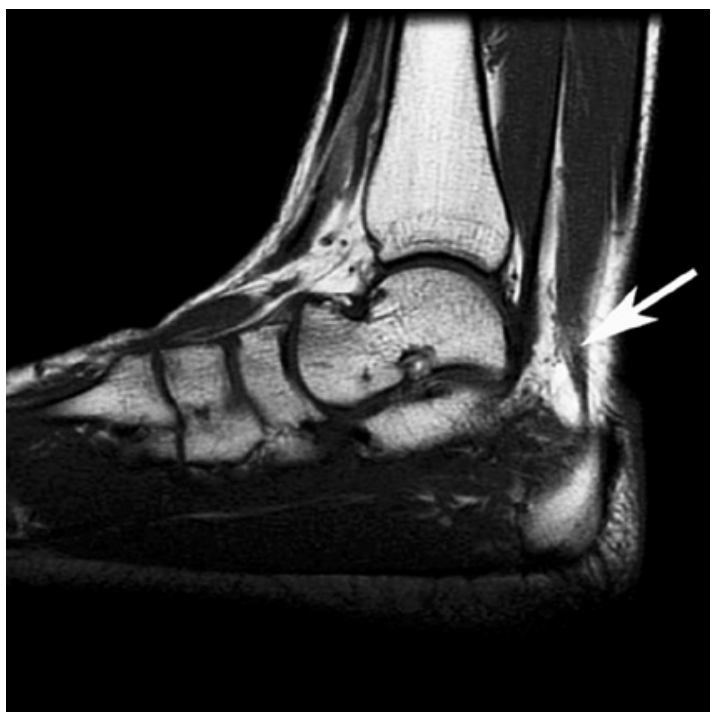

Figure 4. Accessory soleus muscle inserted in the calcaneus bone in sagittal MRI (white arrow)

\section{RESULTS}

There were statistical difference in the prevalence of ASM even when samples were paired according to gender. Out of 154 patients assessed, ASM was found in $18(11.6 \%)$ individuals, 6 were male $(7.8 \%)$ and 12 , female $(15.6 \%)$ (Table 1$)$.

Table 1. Incidence of accessory soleus muscle in humans assessed by magnetic resonance imaging

\begin{tabular}{lcc}
\hline Sample & $\begin{array}{c}\text { Incidence of accessory } \\
\text { soleus muscle }\end{array}$ & $\%$ \\
\hline 77 males & 6 & 7.8 \\
77 females & 12 & 15.6 \\
154 patients & 18 & 11.6 \\
\hline
\end{tabular}




\section{DISCUSSION}

The ASM is usually observed during the second or third decade of life and more often in males, at a 2:1 rate ${ }^{(2-13)}$. To analyze, compare and discuss our findings it was chosen to study the ASM prevalence. This is a rare condition and its general prevalence has not been established yet ${ }^{(14)}$.

Statistical analysis shows that ASM is more frequently a unilateral finding ${ }^{(2)}$. According to our data it was more prevalent in females (15.6\%) when compared to males $(7.8 \%)$, thus differing from most scientific studies reporting greater incidence in males ${ }^{(2-13)}$.

In our study we found that ASM prevalence in humans was of $11.6 \%$. This result corroborates some studies reporting ASM as present in up to $10 \%$ of humans ${ }^{(9,14,15)}$. Moreover, most reports in the literature stated a 0.7 to $5.5 \%$ presence of ASM in human beings ${ }^{(2,3,5,11,13,16-19)}$. Some investigators reported a prevalence ranging from 1 to $6 \%$ in human beings ${ }^{(6,20)}$.

Sometimes it is impossible to precisely identify the ASM origin and insertion, since the MRI fails to show details, depending on the slices. Results may be discrepant according to the ASM variations taken into account by the investigators and the sample that, coincidentally, may include more subjects with ASM.

Our data also showed higher prevalence in females. This could be explained by women's more intense lifestyle and higher physical activity, thus causing ASM symptoms requiring diagnosis and treatment. Currently women have job position they had not before, which require more effort and physical work.

\section{CONCLUSION}

According to literature ASM prevalence is higher in males. Its presence varies between 0.7 and $10.6 \%$. Our study reported a prevalence of $11.6 \%$ in humans and higher prevalence among females than among males.

\section{REFERENCES}

1. Shirkhoda A. Variantes e armadilhas diagnósticas nas imagens do corpo. Rio de Janeiro: Guanabara Koogan; 2003. p 633-4.

2. Sookur PA, Naraghi AM, Bleakney RR, Jalan R, Chan 0 , White LM. Accessorymuscles: anatomy, symptoms and radiology evaluation. Radiographics. 2008;28(2):481-99.

3. Crespo E, Minguez MF, Gascó J, Silvestre A, Jolín T, et al. Músculo sóleo accesorio como diagnóstico diferencial de un tumor de partes blandas del tobillo. Acta Ortop Castellano-Manch. 2004;(5):37-41.

4. Romanus B, Lindahl S, Sterner B. Accessory soleus muscle. A clinical and radiographic presentation of eleven cases. J Bone Joint Surg Am. 1986; 68(5):731-4.

5. Salomão 0, Carvalho Junior AE, Fernandes TD, Romano D, Adachi PP, Sampaio Neto R. Músculo solear acessório: aspectos clínicos e achados cirúrgicos. Rev Bras Ortop. 1994;29(4):251-5.

6. Leswick DA, Chow V, Stoneham GW. Resident's corner. Can Assoc Radiol J. 2003:54(5):313-5.

7. Featherstone T. MRI diagnosis of accessory soleus muscle strain. Br J Sports Med. 1995;29(4):277-8.

8. Doda N, Peh WC, Chawla A. Symptomatic accessory soleus muscle: diagnosis and follow-up on magnetic resonance imaging. Br J Radiol. 2006; 79(946):e129-32.

9. Kouvalchouk JF, Lecocq J, Parier J,Fischer M. [The accessory soleus muscle: a reportof 21 cases and a review of the literature]. Rev Chir Orthop Reparatrice Appar Mot. 2006;91(3):232-8. French.

10. Kurtoglu Z, Uluutku H. Bilateral accessory soleus muscle. Turk J Med Sci. 2000;30:393-5.

11. Santos JA, Gutierrez JA, Cebrian P, Dominguez MG. Músculo soleo accesorio: presentación de un caso y revisión de la bibliografía. Rev Chil Radiol. 2008; $14(2):$ :E9-12.

12. Christodoulou A, Terzidis I, Natsis K, Gigis I, Pournaras J. Soleus accessorius, an anomalous muscle in a young athlete: case report and analysis of the literature. Br J Sport Med. 2004;38(6):e38.

13. Caroll JF. Accessory muscles of the ankle. MRI Web Clinic [Internet].2008 Nov [cited 2012 Jan 31]. Available from: http://www.radsource.us/clinic/0811

14. Sodré H. Músculos anômalos no pé torto eqüino varo congênito. Rev Bras Ortop. 1994;29(1):24-8.

15. Toit MN, de Villiers RV, Derman EW. Persistent pain following ankle sprain: bilateral accessory soleus muscle. S Afr Med J. 2009;99(11):791-2.

16. Mir NA, Kangoo KA. Accessory soleus muscle: a case report and review of the literature. JK Sci. 2002;4(1):41-2.

17. Reis FP, Aragão JA, Fernandes AC, Feitosa VL, Fakhouri R, Nunes MA. The accessory soleus muscle: case report and a review of the literature. Int $J$ Morphol. 2007;25(4):881-4.

18. Singh S, Suri RK Mehta V, Loh H, Arora J, Rath G. Bilateral additional bellies of the soleus muscle: anatomical and clinical insight. Int J Anat Var. 2009;2:20-2.

19. Luck MD, Gordon AG, Beblea JS, Dalinka MK. High association between accessory soleus muscle and Achilles tendonopathy. Skeletal Radiol. 2008; 37(12):1129-33.

20. Meherzi MH, Bouaziz M, Hamida FB, Ghannouchi M, Quertatani M, Nouri H, et al. The accessory soleus muscle: a report of the two cases with review of the literature. Méd Chir Pied. 2009;25(1):17-20. 